KS. PIOTR KROCZEK

Wydział Nauk Społecznych

Uniwersytetu Papieskiego Jana Pawła II w Krakowie

\title{
CZY SYSTEM PRAWA KANONICZNEGO MOŻE BYĆ WZORCEM DLA SYSTEMU PRAWNEGO FEDERACJI PAŃSTW?
}

Treść: Wstęp. - 1. System prawa kanonicznego. - 2. Rozważenie argumentów. - 2.1. Argument $\mathrm{z}$ historii systemów prawnych Europy. - 2.2. Argument z wagi przykładanej do prawa w Kościele. - 2.3. Argument z efektywności prawa kanonicznego. - 2.4. Argument ze źródeł materialnych prawa kanonicznego. - 2.5. Argument z zasad prawa kanonicznego. - Zakończenie.

\section{Wstęp}

Ubi societas ibi ius. Maksymą tą starożytni wyrażali słuszny pogląd, iż każda społeczność ludzka, niezależnie od jej pochodzenia, struktury, celów cechuje się tym, że istnieje w niej fenomen prawa ${ }^{1}$. Efektem tego fenomenu jest to, że życie członków wspólnoty jest regulowane przez normy prawne. Źródłem pochodzenia tych norm może być przykładowo prawo Boże - naturalne lub pozytywne²,

${ }^{1}$ Zob. L. Pospisil, Anthropology of Law: a Comparative Theory, New York 1971, s. 343. Szeroko o tym zagadnieniu pisze np. S. F. Moore, Law and Anthropology, Biennial Review of Anthropology 6 (1969), s. 252-300.

${ }^{2}$ Tak w kan. 199 nr 1: „Praescriptioni obnoxia non sunt iura et obligationes quae sunt legis divinae naturalis aut positivae" z Codex Iuris Canonici auctoritate Ioannis Pauli PP. II promulgatus, 25.01.1983, AAS 75 (1983), cz. 2, s. 1-301; tekst łacińsko-polski: Kodeks Prawa Kanonicznego. Przekład zatwierdzony przez Konferencję Episkopatu, Poznań 1984 (o ile nie zaznaczono inaczej, cytowane kanony pochodzą z tego aktu normatywnego) (dalej: KPK). 
prawo zwyczajowe, czy też prawo stanowione przez kompetentnego prawodawcę.

Normy te niezależnie od źródła, z którego pochodzą, jeżeli spełniają określone przez jurysprudencję wymagania, czyli są generalne, abstrakcyjne, uporządkowane i wzajemnie powiązane, mogą być nazwane systemem prawnym. W tym jednak miejscu trzeba zaznaczyć, że samo pojęcie „systemu prawa” jest pojęciem służącym do ukazania modelu, czyli postulatywnego wzoru, który ma panować w porządku prawnym określonej społeczności. Jest to sposób pojęciowego porządkowania i konceptualizowania prawa obowiązującego w danym miejscu i czasie ${ }^{3}$.

Pytanie, na które niniejszy artykuł ma dać odpowiedź, brzmi: czy system prawa kanonicznego, czyli system prawa obowiązującego w Kościele katolickim, może być wzorcem dla systemu prawnego federacji państw? Odpowiedź na to pytanie może mieć znaczenie praktyczne w kontekście programowego hasła „więcej Europy”. To hasło to część idei zbudowania europejskiej federacji państw, w miejsce obecnie istniejącej unii ${ }^{4}$. Biorąc pod uwagę to, że prawo w Europie zawsze było poważane i cenione ${ }^{5}$, wydaje się, że unifikacja systemów prawnych państw mających taką federację budować mogłaby tę ideę wesprzeć.

${ }^{3}$ A. Bator, System prawa, w: A Bator, W. Gromski, A. Kozak, S. Kaźmierczyk, Z. Pulka, Wprowadzenie do nauk prawnych. Leksykon tematyczny, red. A. Bator, Warszawa 2010, s. 194-196; S. Wronkowska, Podstawowe pojęcia prawa i prawoznawstwa, Poznań 2005, s. 104-111.

${ }^{4}$ Przewodniczący Komisji Europejskiej José Manuel Durão Barroso w Orędziu o stanie Unii w 2012 r. w dniu 12 września 2012 r. wezwał do debaty w sprawie stworzenia europejskiej federacji państw narodowych. Mówił on: „Będziemy musieli dążyć w kierunku federacji państw narodowych. To jest to, czego potrzebujemy. To jest nasz horyzont polityczny (...) Do utworzenia federacji państw narodowych w ostatecznym rozrachunku potrzebny będzie nowy Traktat”. Przemówienie dostępne na stronie http://europa.eu/rapid/pressReleasesAction.do?reference=SPE $\mathrm{ECH} / 12 / 596 \&$ format=HTML\&aged $=0$ \&language $=$ PL\&guiLanguage $=$ en $($ dostęp: 5.10.2014 r.).

${ }^{5}$ R. Sobański, Prawo w Europie, Śląskie Studia Historyczno-Teologiczne 31 (1998), s. $145-156$. 


\section{System prawa kanonicznego}

Na początku trzeba przyjrzeć się bliżej Kościołowi i jego prawu, które, nota bene, jest prawdziwym prawem, a nie prawem jedynie przez analogię do prawa państwowego ${ }^{6}$. Prawo kanoniczne bowiem wypełnia wymagania (principles of legality), które stawia prawdziwemu prawu prawoznawstwo ${ }^{7}$. Prawo kościelne jest: 1) generalne, 2) promulgowane, 3) prospektywne, 4) jasne, 5) logiczne, 6) możliwe do wypełniania, 7) cechujące się stałością ${ }^{8}$.

Należy zauważyć, że miejsce, gdzie prawo kanoniczne jest tworzone i obowiązuje, czyli Kościół katolicki, nie jest monolitem. Kościół katolicki składa się z 23 Kościołów. Te Kościoły to wspólnoty chrześcijan powiązane hierarchią według prawa, które wyraźnie lub milcząco uznane są przez najwyższą władzę Kościoła jako Kościoły sui iuris (por. kan. $27 \mathrm{KKKW}^{9}$ ). Te Kościoły dzielą się na Kościół łaciński (rzymskokatolicki) oraz 22 Kościoły wschodnie. Cechują się one różnymi tradycjami dyscyplinarnymi, ale także teologicznymi i liturgicznymi. Oczywiście, zróżnicowanie pomiędzy Kościołem rzymskim a innymi Kościołami jest dużo większe, niż pomiędzy Kościołami wschodnimi. Jednak wszystkie te wspólnoty są „zespolone jednym Duchem” i „niejako przy pomocy dwóch płuc, Wschodu i Zachodu,

${ }^{6}$ L. Örsy, Corecco's Theology of Canon Law: A Critical Appraisal, The Jurist 53 (1993), s. 194; T. Pawluk, Prawo kanoniczne wedtug Jana Pawła II, t. 1, Olsztyn 1985, s. 28; R. SobAŃski, Nauki podstawowe prawa kanonicznego, t. 1, Teoria prawa kanonicznego, Warszawa 2001, s. 12-16.

${ }^{7} \mathrm{O}$ wymaganiach stawianych prawdziwemu prawu zob. np.: L. Fuller, The Morality of Law, New Haven 1967, s. 39 oraz J. RAz, The Authority of Law. Essays on Law and Morality, Oxford 1979, s. 216-217.

${ }^{8}$ Zob. P. Kroczex, The Art of Legislation: the Principles of Lawgiving in the Church, Kraków 2011, s. 38.

${ }^{9} \mathrm{KKKW}=$ Codex Canonum Ecclesiarum Orientalium auctoritate Ioannis Pauli PP. II promulgatus, 18.10.1990, AAS 82 (1990), s. 1045-1353; tekst łacińsko-polski: Codex Canonum Ecclesiarum Orientalium auctoritate Ioannis Pauli PP. II promulgatus, Kodeks Kanonów Kościołów Wschodnich. Promulgowany przez papieża Jana Pawła II, wydanie polsko-łacińskie, Lublin 2002. 
[jeden Kościół] płonie miłością do Chrystusa jakby jednym sercem z dwiema komorami" ${ }^{\prime 10}$.

Wszystkie katolickie Kościoły mają wspólny trzon ustrojowy. Składają się na niego treść wiary zawarta w dogmatach oraz prawo Boże naturalne i pozytywne. Prawo kanoniczne, jako prawo Kościoła wynikające z jego wiary oraz zawierające prawo Boże, ma tę jedność jeszcze mocniej wyrażać. Jest ono jakby narzędziem zjednoczenia, spajającym cały Kościól ${ }^{11}$. Różne tradycje dyscyplinarne wschodu i zachodu są wyrazem różnorodności Kościoła i wynikają z jego uniwersalizmu, czyli otwartości na wszystkich ludzi. Prowadzi to do wielonarodowościowego i multikulturowego charakteru wspólnoty. Jednak, co należy podkreślić, prawo kanoniczne jest w swoim twardym rdzeniu wyrazem pełnej komunii katolickich Kościołów ${ }^{12}$.

Porządek prawny całego Kościoła opiera się zasadniczo, choć nie wyłącznie, na dwóch kodeksach prawa kanonicznego, czyli kodeksie przeznaczonym dla Kościoła łacińskiego promulgowanym w $1983 \mathrm{r}^{13}$ i kodeksie dla Wschodnich Kościołów katolickich, który ogłoszono w $1988 \mathrm{r} .{ }^{14}$. Te akty normatywne, choć oba są kodeksami, wiele od siebie różni. Ich systematyka, zakres regulacji oraz niektóre rozwią-

\footnotetext{
${ }^{10}$ Joannes Paulus PP. II, Constitutio Apostolica Sacri canones Codex Canonum Ecclesiarum Orientalium promulgatur, 18.10.1990, AAS 82 (1990), s. 1033-1044; polska wersja zaczerpnięta z Codex Canonum Ecclesiarum Orientalium Auctoritate Ioannis Pauli PP. II Promulgatus, Kodeks kanonów Kościołów Wschodnich. Promulgowany przez papieża Jana Pawła II, wydanie polsko-łacińskie, Lublin 2002, s. 28-41, tu s. 33 (dalej: Sacri canones).

${ }^{11}$ Por. Sacri canones, s. 35; Joannes Paulus PP. II, Constitutio Apostolica Pastor Bonus de Romana Curia, 28.06.1988, AAS 80 (1988), s. 841-930, tu nr 2.

${ }^{12}$ Por. J. D. Faris, An Overview of the Code of Canons of the Eastern Churches, w: New Commentary on the Code of Canon Law, red. J. P. Beal, J. A. Coriden, T. J. Green, New York/Mahwah 2000, s. 41.

${ }^{13}$ Codex Iuris Canonici auctoritate Ioannis Pauli PP. II promulgatus, 25.01.1983, AAS 75 (1983), cz. 2, s. 1-301; tekst łacińsko-polski: Kodeks Prawa Kanonicznego. Przekład zatwierdzony przez Konferencję Episkopatu, Poznań 1984.

${ }^{14}$ Codex Canonum Ecclesiarum Orientalium auctoritate Ioannis Pauli PP. II promulgatus, 18.10.1990, AAS 82 (1990), s. 1045-1353; tekst łacińsko-polski: Codex Canonum Ecclesiarum Orientalium auctoritate Ioannis Pauli PP. II promulgatus,
} 
zania prawne są odmienne. Mimo to można mówić o jednym prawie kanonicznym Kościoła katolickiego i, w konsekwencji, o jednym systemie prawnym obowiązującym w Kościele.

Równocześnie system ten cechuje duża spójność. Wyraża to przykładowo fakt, że zarówno KPK, jak i KKKW zawierają kanony, świadczące o wzajemnych bliskich relacjach pomiędzy tymi kodeksami. Takie wzajemne prawne odniesienia mają zwykle charakter wyraźny, a czasami jest on niewyraźny ${ }^{15}$. Poza tym istnieje duże podobieństwo, a niekiedy identyczność w sposobie regulacji spraw dla Kościoła najważniejszych. Do tych wspólnych spraw należą przykładowo te, które z natury rzeczy wiążą wszystkich katolików, np. o najwyższej władzy w Kościele czyli Biskupie Rzymskim (kan. 331 KPK, kan. 43 KKKW) i Kolegium Biskupów (kan. 336 KPK, kan. 49 KKKW). Także wtedy, gdy kanony łacińskiego kodeksu i kodeksu wschodniego przytaczają lub wyjaśniają prawo Boże, zarówno naturalne jak i pozytywne (por. np. kan. $1084 \$ 1$ KPK i $801 \S 1 \mathrm{KKKW}$ ), obowiązuje pełna i niepodważalna łączność pomiędzy Kościołami, wyrażająca się w koherencji systemu prawa kanonicznego. Również kwestie źródeł prawa, interpretacji prawa, reguł walidacyjnych norm, które dla każdego systemu prawa są kluczowe, w wymienionych kodeksach są takie same (por. np. kan. 17-22 KPK i kan. 1504 KKKW).

Takie silne powiązanie Kościoła łacińskiego i Kościołów wschodnich poprzez prawo nie powoduje zatarcia różnic pomiędzy tymi wspólnotami. Przeciwnie, trzeba podkreślić, iż uznając jedność Kościoła najwyższy prawodawca nie pozwala zapomnieć o różnicach w prawie Kościołów (zob. kan. 1 KPK i kan. 1 KKKW). Zawarte w kodeksach dyspozycje mają chronić z jednej strony jedność Kościoła, a z drugiej promować słuszną autonomię wszystkich katolickich Kościołów ${ }^{16}$.

Sumując trzeba stwierdzić, że choć system prawny obowiązujący w Kościele jest prawdziwym system prawny, spełniającym wszystkie

Kodeks Kanonów Kościołów Wschodnich. Promulgowany przez papieża Jana Pawła II, wydanie polsko-łacińskie, Lublin 2002.

${ }^{15}$ Zob. J. Aвbass, Two Codes in Comparison, Kanonika nr 7, Roma 2007, s. 284.

${ }^{16}$ R. SobAŃski, Komentarz do kan. 1, w: J. Krukowski, R. Sobański, Komentarz do Kodeksu Prawa Kanonicznego, t. 1, Księga I, Normy ogólne, Poznań 2003, s. 46 nn. 
wymagania stawianie systemowi prawnemu przez naukę prawa, to jednak jest to system bardzo specyficzny.

\section{Rozważenie argumentów}

Zaprezentowany system prawa kanonicznego trzeba przeanalizować jako potencjalny wzorzec dla innego systemu normatywnego. Dogodną metodą, jaką można się posłużyć, jest metoda scholastyków sic et non. Zgodnie z nią zostaną najpierw wysunięte argumenty uporządkowane, w kolejności od ogólnych do szczegółowych, pozwalające na pozytywną odpowiedź na postawione w tytule artykułu pytanie badawcze, a następnie podane zostaną kontrargumenty.

\subsection{Argument $\mathrm{z}$ historii systemów prawnych Europy}

Pro. Działając zgodnie z metodologiczną zasadą, nakazującą zbadanie historii komentowanego zagadnienia (historia est magistra vitae), należy zauważyć, że prawo kościelne stanowiło już w przeszłości wzorzec dla prawa europejskiego.

W średniowieczu cechą charakterystyczną prawa w Europie był jego partykularyzm. Normy prawne nie miały charakteru powszechnego. Wynikało to z tego, iż podstawą regulacji prawnych było głównie prawo zwyczajowe. Normy prawne pochodzące z tego źródła, zgodnie ze swoim charakterem, tworzyły się lokalnie i najczęściej miały moc wiązania swoich adresatów tylko w określonym miejscu.

Powstawanie w Europie scentralizowanej monarchii stanowej spowodowało potrzebę unifikacji lokalnych praw zwyczajowych. W związku z tym pojawiły się tendencje, zmierzające do likwidacji prawnego partykularyzmu. W realizacji tych zamierzeń pomocne były systemy prawne, które w swych założeniach miały charakter powszechny, tj. prawo rzymskie i właśnie prawo kanoniczne. Dzięki m.in cesze uniwersalizmu przenikały one do praktyki prawnej w charakterze prawa powszechnego (ius commune) ${ }^{17}$. W Europie ius commune stanowiło podstawę dla wielu systemów prawnych aż do XIX wieku,

\footnotetext{
${ }^{17}$ K. SójKa-ZielińsKa, Historia prawa, Warszawa 2009, s. 37 i s. 60. Cenną pozycją na ten temat jest M. Betlomo, Storia del diritto comune, Rome 1989.
} 
a w niektórych dziedzinach prawa nawet do XX wieku ${ }^{18}$. Można więc przyjąć, że łączenie systemów praw państwowych mogło by nastąpić ponownie w oparciu o prawo kościelne.

Sed contra. Przyjmując za niepodważalny fakt roli integrującej prawa kanonicznego w systemach prawnych państw Europy, trzeba zauważyć, że ten charakter wiązał się z recepcją przez te systemy zasad, wartości i konkretnych regulacji prawnych obecnych pierwotnie w prawie kościelnym. Wydaje się, że proces laicyzacji prawa, który nastąpił w Europie począwszy od XVIII wieku, a wyraźnie widoczny przykładowo w prawie małżeńskim czy prawie karnym, doprowadził do sytuacji, w której korzystanie z wzorca prawa religijnego jest ze względów aksjologicznych niemożliwe ${ }^{19}$. Obecnie systemy prawne, choć oczywiście związane z moralnością poprzez określone regulacje i relacje funkcjonalne ${ }^{20}$, jawią się jako wyodrębnione i autonomiczne regulatory życia społeczeństw ${ }^{21}$.

Dodatkowo należy zauważyć, że choć ius commune stanowiło powszechną podstawę prawa materialnego i proceduralnego, to zasadniczo tylko w świecie chrześcijańskim ${ }^{22}$. W obecnej Europie, którą cechuje laickość i multireligijność, nie wydaje się, aby model prawa ius commune oparty o chrześcijaństwo był możliwy do przyjęcia.

2.2. Argument z wagi przykładanej do prawa w Kościele

Pro. Argumentem za traktowaniem prawa kanonicznego jako wzorcowego dla innych systemów prawnych jest deklaratywnie

\footnotetext{
${ }^{18}$ J. A. Brundage, Medieval Canon Law, London/New York 1995, s. 174.

${ }^{19}$ Zob. więcej: K. SójKA-Zielińska, Historia prawa, Warszawa 2009, s. 214, s. 240, s. 272.

${ }^{20}$ Zob. np. w polskim prawie karnym art. $148 \$ 1$ odpowiada zasadniczo normatywnie V Przykazaniu Bożemu. Także określenia wartościujące np. „szczególne okrucieństwo" z art. $148 \$ 2$ pkt 1, art. $197 \$ 4$, art. $207 \$ 2$, art. $247 \$ 2$ ustawy z dnia 6 czerwca 1997 r. - Kodeks karny (Dz.U. Nr 88 poz. 553 z późn. zm.) należy interpretować w odniesieniu do moralności. Zob. na ten temat np. L. Morawski, Wstęp do prawoznawstwa, Toruń 2009, s. 39-47.

${ }^{21}$ R. Sobański, Prawo jako wartość, Prawo Kanoniczne 42 (1999) nr 3-4, s. 11.

${ }^{22}$ J. A. Brundage, Medieval Canon Law, London/New York 1995, s. 58.
} 
wysoki poziom kultury prawnej panującej w Kościele. Ten rodzaj kultury wyraża się w postawie wiernych wobec prawa, polegający na szacunku wobec norm prawnych, rozumieniu znaczenia instytucji prawnych i świadomości hierarchii i wiernych, co do roli i celów prawa obowiązującego w Kościele ${ }^{23}$. Poziom tego rodzaju kultury jest wynikiem tego, że prawo należy do istoty Kościoła i jest w tej wspólnocie postrzegane jako niezbędne narzędzie do organizowania życia. Jak to wyraził papież Jan Paweł II we Wstępie do Kodeksu Prawa Kanonicznego z 1983 r.: „sana ordinatio iuridica prorsus necessaria est ut ecclesiastica communitas vigeat, crescat, floreat" ${ }^{24}$. Z pewnością jest pożądane, aby każdy system prawny cieszył się tak wielkim szacunkiem i zaufaniem jako zespół norm rzeczywiście potrzebny, stanowiący bowiem o istocie społeczności, w której obowiązuje.

Sed contra. Jako kontrargument wypada podnieść to, że od początku istnieją w Kościele ruchy antyjurydyczne. Można je obserwować także współcześnie. Ruchy te widzą w prawie element zbędny, a nawet szkodliwy dla wspólnoty wierzących. Według założeń tych ruchów wierni powinni się kierować nie nakazem prawnym, lecz samą miłością. Prawo w ich rozumieniu należy do początku doczesnego, ziemskiego, a więc nie należy do istoty Kościoła ${ }^{25}$.

Dodatkowo należy stwierdzić, że kultura prawna wyrażająca się przykładowo w poziomie prawodawstwa kościelnego, stopniu

${ }^{23}$ Szerzej na ten temat, zob. R. Sobański, Prawo kanoniczne a kultura prawna, Prawo Kanoniczne 35(1992) nr 1-2, s. 15-33; tenże, Uwagi o miejscu prawa kanonicznego w kulturze prawnej, w: W kierunku religijności, red. B. Bejze, Warszawa 1983, s. 268-282. Na temat pojęcia „kultura prawna” zob. np.: K. OpAŁEK, Zagadnienia teorii prawa i teorii polityki, Warszawa 1986, s. 273-296.

${ }^{24}$ Praefatio do Codex Iuris Canonici auctoritate Ioannis Pauli PP. II promulgatus, AAS 75(1983), t. 2, s. XVII-XXX; tu s. XXX; tekst łacińsko-polski: Wstęp do Kodeksu Prawa Kanonicznego. Przekład zatwierdzony przez Konferencję Episkopatu, Poznań 1984, s. 37: „zdrowy porządek prawny jest na pewno konieczny, aby wspólnota kościelna żyła, wzrastała, kwitła”.

${ }^{25} \mathrm{Na}$ temat tych ruchów, zob. R. C. LARA, Some Reflections of the Proper Way to Approach the Code of Canon Law, CLSA Proceedings 46 (1984), s. 27-28. Ruchy te mocno skrytykował papież Pius XII w Litterae encyclicae Mystici Corporis Christi, 29.06.1943, AAS 35 (1943), s. 193-248. 
znajomości regulacji kanonicznych, a także w gorliwości przestrzegania przez wiernych oraz stosowania przez organy władzy kościelnej norm kanoniczych, nie dorównują wspominanej deklaracji papieża Jana Pawła II odnośnie do szacunku dla prawa w Kościele ${ }^{26}$.

\subsection{Argument $\mathrm{z}$ efektywności prawa kanonicznego}

Pro. Efektywność prawa jest zagadnieniem rzadko podejmowanym w teorii prawa ${ }^{27}$. Efektywność prawa to jego cecha, która wyraża się w tym, że prawo oddziałuje skutecznie na swoich adresatów. Oznacza to, że widać wpływ norm prawnych na życie wspólnoty, której dotyczy. Efektywne prawo to takie, które jest przestrzegane i stosowane.

Należy stwierdzić, że system prawa kanonicznego jest efektywny ${ }^{28}$. Normy w nim zawarte regulują życie ponad miliarda wiernych. Jego skuteczność wyraża się także przez to, że Kościół, choć nie ma do dyspozycji, w przeciwieństwie do państwa, środków przymusu bezpośredniego, utrzymuje w karności i dyscyplinie swoich wiernych. Wszelkie kary, jakie może stosować kompetentny przełożony kościelny, zasadniczo wiążą się wyłącznie z pozbawieniem osoby dobra duchowego ${ }^{29}$.

Sed contra. Trzeba jednak w formie kontrargumentu zauważyć, że zakres regulacji systemu kościelnego jest niewielki w porównaniu z prawem obowiązującym we współczesnych państwach. Efektywność oddziaływania prawa o niewielkim zakresie regulacji, jest siłą

\footnotetext{
${ }^{26}$ Zob. na ten temat P. Kroczen, The Art of Legislation: the Principles of Lawgiving in the Church, Kraków 2011, s. 7.

${ }^{27}$ S. Wronkowska, Z. Ziembiński, Zarys teorii prawa, Poznań 1997, s. 212; R. SoBAŃsKi, Kościół jako podmiot prawa. Elementy eklezjologii prawnej, Warszawa 1983, s. 172.

${ }^{28} \mathrm{O}$ warunkach tej efektywności zob. P. KRoczeK, Kiedy prawo kanoniczne jest efektywne?, Annales Canonici 2 (2006), s. 163-177.

${ }^{29}$ Zob. kan. 2215: „Poena ecclesiastica est privatio alicuius boni ad delinquentis correctionem et delicti punitionem a legitima auctoritate inflicta" w Codex Iuris Canonici. Pii X Pontificis Maximi iussu digestus, Benedicti Papae XV auctoritate promulgatus, AAS 9 (1917), cz. II, s. 11-456.
} 
rzeczy większa niż regulacje dotyczące wielu aspektów życia adresatów. Gałęzie prawa kanonicznego są bardzo nieliczne w zestawieniu $\mathrm{z}$ gałęziami prawa państwowego ${ }^{30}$. Zresztą prawodawca kościelny jest świadomy tego, że system prawa kanonicznego nie obejmuje całościowo życia wiernych Kościoła. Nie jest to jednak wcale potrzebne. Prawodawca kościelny nie ma ambicji stanowienia konkurencyjnego systemu prawnego wobec systemu prawa państwowego.

Poza tym efektywność prawa kościelnego ma swoje źródło także w tym, że niektóre argumenty za przestrzeganiem norm prawa kanonicznego mają inny charakter niż argumenty za przestrzeganiem prawa stanowionego przez władzę państwową. Głównym bowiem motywem poszanowania prawa kościelnego jest wiara adresatów prawa i troska o własne zbawienie. Takiego ultima ratio nie może mieć państwo i jego prawo, które ze swej natury jest zawsze powiązane z przymusem i ogranicza się do ziemskiej doczesności.

\subsection{Argument ze źródeł materialnych prawa kanonicznego}

Pro. Jeżeli wziąć pod uwagę kryterium odrębności źródeł prawa, to można wyróżnić główne dwa typy systemów prawnych: system prawa kontynentalnego (civil law) i system anglosaskiego (common law) ${ }^{31}$. Ten pierwszy charakteryzuje się tym, że głównym źródłem norm jest fakt prawotwórczy w postaci stanowienia norm przez kompetentnego prawodawcę. Prymatem cieszy się więc ustawa. Z kolei w systemie anglosaskim - choć i w tym systemie ustawa jest najwyższym źródłem prawa - istotnym faktem, który decyduje o powstaniu normy, jest precedens prawotwórczy. W tym typie systemu ważną rolę odgrywa prawo zwyczajowe.

\footnotetext{
${ }^{30} \mathrm{~W}$ prawie kanonicznym można mówić o kodeksowych gałęziach prawa: konstytucyjnego, administracyjnego, sakramentalnego, małżeńskiego, dóbr doczesnych, prawa procesowego i karnego. Natomiast pozakodeksowe to np.: gałąź prawa kanonizacyjnego.

${ }^{31}$ Oczywiście można wskazać i inne typy systemów prawnych: systemy prawa Dalekiego Wschodu, Islamu, hinduskiego, afrykańskiego, zob. L. MoRAWski, Wstęp do prawoznawstwa, Toruń 2009, s. 67.
} 
Prawo kościelne może być dobrym wzorcem zbalansowanego korzystania ze źródeł materialnych: prawa pisanego i prawa zwyczajowego. Są one przecież równorzędnymi źródłami norm dla wiernych. Takie rozwiązanie źródeł norm mogłoby więc służyć unifikacji wymienionych typów systemów prawnych, obecnych przecież w Europie.

Sed contra. Choć w systemie prawa kanonicznego są obecne normy z prawa zwyczajowego, to ze względów praktycznych nie są one reprezentowane szeroko. $\mathrm{W}$ przypadku bowiem ich stosowania można napotkać na trudności z określeniem normatywnego charakteru istniejącego w określonej społeczności zwyczaju. Także interpretacja norm prawa zwyczajowego, ich obowiązywanie oraz zakres stosowania są kłopotliwe.

Podobnie i współczesne państwowe systemy prawne, nawet typu common law, odchodzą od prawa zwyczajowego ${ }^{32}$. Ustawa zaczyna być dominującym źródłem norm prawnych, jako tym, które jest pewniejsze. Także w odniesieniu do prawa kościelnego niektórzy kanoniści, nie bez szeregu racji, podnosili potrzebę odrzucenia prawa zwyczajowego na korzyść ustawy ${ }^{33}$. Dzięki takiemu rozwiązaniu kwestia bardzo ważna w systemach prawnych jak hierarchia źródeł prawa, czyli jednoznaczne wskazanie ich mocy prawnej byłaby jasna i czytelna ${ }^{34}$.

${ }^{32}$ S. Wronkowska, Podstawowe pojęcia prawa i prawoznawstwa, Poznań 2005, s. 99-100.

${ }^{33}$ R. Sobański, Zwyczaj, w: J. Krukowski, R. Sobański, Komentarz do Kodeksu Prawa Kanonicznego, t. 1, Księga I, Normy ogólne, Poznań 2003, s. 78. Odrzucenie prawa zwyczajowego postulowane rozwiązanie jest, jak się wydaje, nie do przyjęcia przez Kościół, prawo zwyczajowe bowiem ukazuje jedność pomiędzy Ludem Bożym a Duchem Świętym (por. kan. 1506 KKKW).

${ }^{34}$ Zob. przykładowo jasne wyłożenie źródeł prawa w systemie prawa polskiego w art. 87-94 Konstytucji Rzeczypospolitej Polskiej z dnia 2 kwietnia 1997 r. (Dz.U. Nr 78, poz. 483 z późn. zm. i sprostowaniem). Nota bene w prawie kościelnym nawet wśród źródeł prawa pisanego panuje brak przejrzystości co do ich hierarchii, zob. na ten temat: R. SoBAŃski, Teoria prawa kościelnego, s. 147, zaś szerzej o tym problemie zob. P. Kroczen, The Art of Legislation: the Principles of Lawgiving in the Church, Kraków 2011, s. 200-202. 


\subsection{Argument $\mathrm{z}$ zasad prawa kanonicznego}

Pro. System prawa kanonicznego zawiera zasady prawne, które służą ochronie i obronie poziomu prawa i wartości, odnoszonych zwykle do systemu prawa takich, jak: stałość, przewidywalność, użyteczność. Chodzi na przykład o zasadę zabraniającą prawodawcy stanowienia prawa działającego wstecz (lex retro non agit) zawartą w kan. 9. Istnieją także inne zasady, przykładowo aequitas canonica (kan. 19), czyli zasada nakazująca stanowienie prawa, jego interpretację i stosowanie z zachowaniem należnej słuszności, delikatności, ludzkiego podejścia ${ }^{35}$. Principia te mogą stanowić wzorzec i pomoc dla twórców nowego systemu prawnego Europy.

Sed contra. Po pierwsze, zasady, których obecność w prawie kanonicznym jest dość znacząca, pochodzą z prawa rzymskiego. Jego reguły i instytucje nie zawsze są obecne w prawie common law, w którym zasadniczo nie dokonała się recepcja prawa rzymskiego. Po drugie, wspomniane zasady, choć oczywiście obecne w prawie kanonicznym, doznają rozszerzenia albo ograniczenia w takim zakresie, który dla współczesnych państw jest nie do przyjęcia. Zbyt często stricte teologiczne argumenty modyfikują te zasady. Przykładowo retrospekcja jest dozwolona dla Prawa Bożego, a o tym, co jest prawem Bożym, może autentycznie wyjaśniać jedynie najwyższa władza kościelna (por. kan. $1075 \$ 1$ ). Dodatkowo, wiele z kanonicznych zasad prawnych jest zbyt typowych dla prawa specyficznej społeczności, jaką jest Kościól, i w praktyce innych społeczności nie jest spotykane, np. tolerantia canonica, dissimulatio, dispensatio ${ }^{36}$.

${ }^{35}$ Wstęp do Kodeksu Prawa Kanonicznego. Przekład zatwierdzony przez Konferencję Episkopatu, Poznań 1984, s. 25.

${ }^{36}$ Tolerantia canonica polega na tym, iż przełożony kościelny wyraźnie lub milcząco pozwala na nieposłuszeństwo określonym normom prawa kościelnego lub pozwala na przestrzeganie norm sprzecznych z nimi, np. pochodzących z prawa państwowego; dissimulatio to sytuacja, w której władza kościelna z pozoru nie zwraca uwagi na dyscyplinę kościelną i tym samym zezwala na nieprzestrzeganie prawa; dispensatio, czyli dyspensa to rozluźnienie prawa czysto kościelnego w poszczególnym przypadku (kan. 85); zob. P. Kroczeк, The Art of Legislation: the Principles of Lawgiving in the Church, Kraków 2011, s. 241-244. 


\section{Zakończenie}

Obecnie w Europie rozbrzmiewa idea stworzenia federacji państw. Jej utworzenie prawdopodobnie wiązałoby się ze stworzeniem nowego systemu prawnego, łączącego podmioty, które miałyby wejść w tę federację. Każda społeczność bowiem, także o charakterze federacji, potrzebuje jednolitych i wewnętrznie niesprzecznych regulacji prawnych, w przeciwnym razie będzie panował w niej chaos lub anarchia $^{37}$. Stworzenie takiego systemu prawnego jest zależne od wielu czynników. Należą do nich czynniki polityczne, kulturowe, prawne, ekonomiczne, społeczne, geograficzne, religijne. Te czynniki są modyfikatorami norm prawa materialnego, ustrojowego i procesowego (ius sequitur vitam).

Na pytanie badawcze, zawarte w tytule artykułu, trzeba odpowiedzieć negative. Po rozważeniu argumentów trzeba stwierdzić, że programowa unifikacja obecnie istniejących systemów prawnych w Europie poprzez zapożyczenie z wzorca, czyli z systemu prawa kanonicznego, zapewne nie przyniesie pożądanych rezultatów w postaci nowego systemu prawnego, który miałby pomóc w połączeniu w jedność różnorodności przy zachowaniu różnorodności w jedności (unitas in diversitate et diversitas in unitate).

Jako kluczową przyczynę niepowodzenia tego zamierzenia trzeba wskazać to, że każdy system prawa rodzi się na określonym fundamencie, jakim jest społeczność ludzka. A Kościół i państwo (oczywiście, także i federacyjne) mają odmienną genezę, różne cele i odrębne środki, a co z tym idzie inne prawo.

Jak się wydaje, nic nie stoi na przeszkodzie, aby prawodawcy państwowi (vel federacyjni) byli otwarci na rozwiązania wypracowane przez kanonistykę ${ }^{38}$. Z woli najwyższego prawodawcy w Kościele

\footnotetext{
${ }^{37}$ Zob. T. GaŁkowski, Ubi societas ibi ius w czasach globalizacji, w: Ars boni et aequi. Księga pamiątkowa dedykowana księdzu profesorowi Remigiuszowi Sobańskiemu z okazji osiemdziesiątej rocznicy urodzin, red. J. Wroceński, H. Pietrzak, Warszawa 2010, s. 615-616.

${ }^{38}$ Nota bene to właśnie współpraca, oprócz niezależności i autonomii, ma charakteryzować stosunki państwa i Kościoła, zob. Sacrosanctum Concilium OecumeNicUm VATiCAnUm II, Constitutio pastoralis Gaudium et spes de Ecclesia in mundo
} 
taka otwartość istnieje wśród kanonistów, np. poprzez przepis kan. 22, który nakazuje, aby zachować w porządku kanonicznym ustawy państwowe, do których odsyła prawo kościelne, o ile oczywiście nie są one przeciwne prawu Bożemu i o ile prawo kanoniczne czego innego nie zastrzega.

Trzeba jednak zauważyć, że równoległe istnienie wielu systemów prawnych, a szczególnie sytemu prawa kanonicznego i systemu prawa państwowego, prowadzi nieuchronnie do rywalizacji pomiędzy nimi o człowieka, który podlega obu tym porządkom prawnym. Wydaje się, że należy popierać tę rywalizację. Nie ma przesady w twierdzeniu, iż ta rywalizacja „była jedną $\mathrm{z}$ decydujących sił napędowych formowania się cywilizacji europejskiej"39. Być może taką rolę odegra i w formującym się obecnie nowym porządku w Europie.

\section{Can the system of canon law be a pattern for a legal system of federation of states?}

The main question of the article is as follows: Can the system of canon law be a pattern for a legal system of federation of states? The answer to this question has a practical dimension in the context of the declaration of policy - "more Europe in the European Union", which is call for transferring the present union of states into a federation of states. The paper discuses several arguments, like: argument of the history of European legal systems,

huius temporis, 7.12.1965, AAS 58 (1966), s. 1025-1115; tekst łacińsko-polski: SoBóR WATYKAŃSKi II, Konstytucja duszpasterska Gaudium et spes o Kościele w świecie współczesnym, w: Sobór Watykański II, Konstytucje, dekrety, deklaracje, Poznań 1986, s. 811-987, tu nr 76. Por. art. 25 ust. 3 Konstytucji RP oraz wstęp do ustawy z dnia 17 maja 1989 r. o stosunku Państwa do Kościoła Katolickiego w Rzeczypospolitej Polskiej (Dz. U. Nr 29, poz. 154 z późn. zm.). Zob. szerzej: np. J. KRUKOWSKI, Problematyka relacji między Kościołem i państwem na Soborze Watykańskim II, Życie i myśl 12 (1980), s. 40-54; O. Chaline, Między dwiema społecznościami: Kościół Chrystusowy a współczesne państwa, Communio 3 (135) 2003, s. 3-4. Nawet po odrzuceniu wspomnianych zasad współistnienia Kościoła i państwa wzajemna naukowa otwartość jest możliwa na zasadzie fas est et ab hoste doceri.

${ }^{39}$ R. Sobański, Czy prawo kościelne jest dziwne, Śląskie Studia Historyczno-Teologiczne 35 (2002), s. 426-427. 
argument of the significance of law in Europe, argument of effectiveness of canon law, argument of material sources of canon law, argument of principles of canon law. All of the arguments are presented in accordance with scholastic methods and arguments pro and contra are juxtaposed. The answer for the research question is: negative.

SŁOWA KLUCzOWE: system prawa kanonicznego, system prawny, Unia Europejska, federacja państw.

KeYwORDS: system of canon law, legal system, United Europe, federation of countries.

Nota o Autorze:

Ks. DR hab. Piotr Kroczek, Prof. UPJPII - pracownik naukowo-dydaktyczny na Wydziale Nauk Społecznych Uniwersytetu Papieskiego Jana Pawła II w Krakowie, kierownik Katedry prawa rodzinnego, autor licznych prac z zakresu kanonicznego prawa małżeńskiego i wyznaniowego. 